\title{
EFFECTS OF NITROGEN AND ZINC TREATMENTS AT DIFFERENT DOSES ON MAIZE YIELD AND YIELD COMPONENTS UNDER KAHRAMANMARAŞ CONDITIONS
}

\author{
Cengiz Yururdurmaz ${ }^{1, *}$, Ali Turan ${ }^{1}$ \\ ${ }^{1} \mathrm{KSU}$ Faculty of Agriculture Department of Field Crop Kahramanmaraş, Turkey
}

Current Trends in

Natural Sciences

\begin{abstract}
This study was carried out in 2019 in Kahramanmaraş University Field Crops Department to determine nitrogen and zinc fertilizer needs of maize plants in Kahramanmaraş Region. Experiments were conducted in split-plots design with 3 replications. Soil nitrogenous fertilizer (Urea) treatments were arranged as: $0 \mathrm{~kg} / \mathrm{da}(\mathrm{NO}), 15 \mathrm{~kg} / \mathrm{da}(\mathrm{N15}), 30 \mathrm{~kg} / \mathrm{da}$ (N30). Foliar zinc treatments were arranged as 0 ppm (Zn0), 2500 ppm (Zn5), 5000 ppm (Zn10). Dekalp DKC6890 hybrid maize variety was used as the plant material of the experiments. Present findings revealed that nitrogen and zinc treatments had significant effects on the first cob height, cob length, cob thickness, number of rows per cob, number of kernels per cob and kernel yield of maize plants, but the effects of nitrogen and zinc treatments on plant height and thousand kernel weight were not found to be significant.
\end{abstract}

Keywords: Maize, Nitrogen level, Zinc level, Yield, Yield components

\section{INTRODUCTION}

Maize (Zea mays L.), belonging to the family of Gramineae, is a foreign-pollinating, warm -season cereal adapted to different climates. It constitutes an important source income for farmers worldwide (Shaw, 1988). With increasing populations, maize have become a popular cereal both in the world and Turkey. Maize is used in both human nutrition and animal feeding. It is also used in various sectors of the industry. Just because of high unit area yields and silage yields, it is a popular crop of the farmers and because of kernel starch, sugar and oil contents, it is a highly popular crop among industry specialists. A fully-ripened maize kernel contains $70 \%$ starch, $10 \%$ protein, $2 \%$ sugar and 2\% ash (Kün, 1994). In recent years, potential use of maize in biodiesel production have increased the demands for maize crop. After wheat and paddy, maize has the third largest cultivation area (185.121.342 ha), but has the greatest unit area yield (933 kg da) among the cereals (Anonymous, 2019a).

In Turkey, maize consumptions have increased with increasing populations and the annual consumption per capita reached to $57 \mathrm{~kg}$ (Şehirali et al., 2000). Worldwide, maize is mostly cultivated in American Continent. The USA is the leading maize producer and meets about 40-45\% of world production (Babaoğlu, 2005). Following the USA, China, Azerbaijan, Brazil and Mexico are the other large maize producers of the world. 
In Turkey, maize was cultivated in 510.000 ha land area and annual production was 3.500 .000 tons in 2007. The maize cultivated lands increased to 639.000 ha and annual production increased to 6.000.000 tons in 2019. Maize could be cultivated as the main or second crop. Especially in GAP (Southeastern Anatolia Project) region, maize production has increased with increasing irrigated lands.

Maize is included in C-4 plants and requires significant quantity of nitrogen throughout the growth and development of the plant. Nitrogen is used in protein synthesis, DNA and RNA-like metabolic processes of the plants (Bozcuk, 1986). Maize uptakes quite large quantities of nutrients from the soil and maize nitrogen uptake largely relies on soil texture, moisture, temperature and irrigation (Sencar, 1988). Fertilization is essential in agricultural fields for high yields. Insufficient nitrogen levels of the soils constitute significant limitations in maize cultivation (Demari et al., 2016). Nitrogen is needed from the initial growth stages of the plants. Since maize plants are not sufficiently benefit from the nitrogen over the soil surface, nitrogen deficiency should be met through fertilization. Zinc deficiency is encountered in world soils and Turkish soils. Zinc deficiency is seen either because of insufficient zinc levels of the soils or unavailable forms of zinc for plant uptake (Dumral, 2015).

Besides high yields, quality is also a significant criterion in maize cultivation based on purpose of growth. Seed quality is largely influenced by genotypes, growing conditions, storage, disease and pests and the other environmental factors (Maiti and Wesche-Ebeling, 1998). Zinc deficiency is seen in people of countries fed largely on cereals. Therefore, enriching cereal grains in zinc through fertilization will also positively influence human health (Brohi et al., 2000). Zinc deficiency in maize plants manifests itself from the initial growth stage. Under zinc deficiency, internodes are shortened and shape deformations or malformation is encountered in cobs (Çolakoğlu, 2010). Since maize more benefit from sunlight than the other cereals, it could produce greater quantities of dry matter. Therefore, supply of fertilizers and nutrients at proper quantities may improve maize yields (Çolakoğlu, 2010). This study was conducted to determine nitrogenous and zinc fertilizer needs of maize plants.

\section{MATERIALS AND METHODS}

This study was conducted over the experimental fields of Kahramanmaraş Sütçü İmam University Agricultural Faculty in 2019 as the main crop. Kahramanmaraş province is located in Mediterranean region between 370 38' north latitudes and 360 37' east longitudes and average altitude of the province is $568 \mathrm{~m}$. Mediterranean climate is dominant in the region. Winters are warm and rainy, summers are hot and dry, day/night temperature difference is low. Dekalp DKC6890 hybrid maize cultivar was used as the plant material of the study.

Experiments were conducted in split-plots experimental design with 3 replications. Plots were $5 \mathrm{~m}$ long, row spacing was $0.70 \mathrm{~m}$ and on-row plant spacing was $0.20 \mathrm{~m}$. Each plot had 4 rows planted. Plot size was $4 \times 0.70 \mathrm{~m} \times 5 \mathrm{~m}=14 \mathrm{~m} 2$. Soil nitrogenous fertilizer treatments (urea) were arranged as N0 (0 kg/da), N15 (15 kg/da) and N30 (30 kg/da). The first half of the nitrogenous fertilizer was applied at sowing and the other half was applied when the plants reached to 3-leaf stage. Foliar zinc treatments were arranged as $\mathrm{Zn} 0(0 \mathrm{ppm}), \mathrm{Zn} 5(2500 \mathrm{ppm})$ and $\mathrm{Zn} 10(5000 \mathrm{ppm})$ in the form of $\mathrm{ZnSO} 4.7 \mathrm{H} 2 \mathrm{O}$ and applications were made at 3-4 leaf stage of the plants.

At harvests, one row from each side and $50 \mathrm{~cm}$ from the top and bottom of the plots were omitted as to consider side effects. Measurement, counting and blending of harvested plants were conducted and average of measurement values were taken. 


\section{Current Trends in Natural Sciences}

Vol. 10, Issue 19, pp. 252-259, 2021

https://doi.org/10.47068/ctns.2021.v10i19.033

Current Trends in Natural Sciences (on-line)

Plant height, the first cob height, stalk diameter, number of nodes, cob thickness, cob length, number of rows per cob, number of kernels per cob, single cob yield, thousand kernel weight and yield per decare were determined in accordance with the methods specified in West et al. (1920), Evans (1972), Gençkan (1976), Sencar (1988), Engin et al. (1989), Ülger (1986), Cihangir (2013) and Yürürdurmaz (2007). Experimental data were subjected to analysis of variance with the use of SAS software and significant means were compared with the use of Duncan's multiple range test (SAS, 1999).

\section{RESULTS AND DISCUSSIONS}

In terms of nitrogen and zinc doses, significant differences were observed in investigated parameters (except for plant height)

The greatest plant height $(151.6 \mathrm{~cm})$ was observed in N30 treatment, it was followed by N15 treatment $(149.2 \mathrm{~cm})$ and the lowest plant height $(141.4 \mathrm{~cm})$ was observed in N0 treatment. Nitrogenous fertilizers promote vegetative development of the plant (Gökmen et al., 2001, Kün, 1994), thus increase plant height. Similar with the present findings, Ülger et al. (1996), Gözübenli (1997), Flesch and Viera (2000), Turgut (2000), El Hattab et al. (1980), Ülger et al. (1986) and Ogunlela et al. (1988) reported increasing plant heights with increasing nitrogenous fertilizer doses. Zinc doses did not have significant effects on plant heights. The greatest plant height was obtained from $\mathrm{Zn}_{5}(149.4 \mathrm{~cm})$, it was followed by $\mathrm{Zn}_{0}(149.1 \mathrm{~cm})$ treatment and the lowest plant height $(143.6$ $\mathrm{cm})$ was obtained from $\mathrm{Zn}_{10}$ treatment.

\begin{tabular}{lllll}
\multicolumn{6}{l}{ Table 1. Effects of nitrogen and zinc doses on plant height, the first cob height, cob thickness and cob length } \\
\hline $\begin{array}{llll}\text { Nitrogen } \\
\text { Doses }(\mathrm{kg} / \mathrm{da})\end{array}$ & $\begin{array}{l}\text { Plant Height } \\
(\mathrm{cm})\end{array}$ & $\begin{array}{l}\text { First Cob } \\
\text { Height }(\mathrm{cm})\end{array}$ & $\begin{array}{l}\text { Cob Thickness } \\
(\mathrm{mm})\end{array}$ & $\begin{array}{l}\text { Cob Length } \\
(\mathrm{cm})\end{array}$ \\
\hline $\mathrm{N} 0$ & $141.4 \mathrm{~b}$ & $51.58 \mathrm{c}$ & $42.41 \mathrm{~b}$ & $14.91 \mathrm{c}$ \\
$\mathrm{N} 15$ & $149.2 \mathrm{a}$ & $53.67 \mathrm{~b}$ & $46.04 \mathrm{a}$ & $17.30 \mathrm{~b}$ \\
$\mathrm{~N} 30$ & $151.6 \mathrm{a}$ & $55.34 \mathrm{a}$ & $45.53 \mathrm{a}$ & $17.84 \mathrm{a}$ \\
\hline LSD & 7.71 & 1.33 & 1.35 & 0.32 \\
\hline Zinc Doses & & & & \\
$(\mathrm{ppm})$ & & & & \\
\hline Zn0 & $149.1 \mathrm{a}$ & $55.60 \mathrm{a}$ & $45.87 \mathrm{a}$ & $16.51 \mathrm{~b}$ \\
Zn5 & $149.4 \mathrm{a}$ & $52.60 \mathrm{~b}$ & $44.78 \mathrm{a}$ & $16.70 \mathrm{ab}$ \\
Zn10 & $143.6 \mathrm{a}$ & $52.41 \mathrm{~b}$ & $43.38 \mathrm{~b}$ & $16.84 \mathrm{a}$ \\
\hline LSD & 7.71 & 7.72 & 1.35 & 0.32 \\
CV $(\%)$ & 5.09 & 2.42 & 2.94 & 1.90 \\
\hline
\end{tabular}

** Significant at $\mathrm{P}<0.01$, * Significant at $\mathrm{P}<0.05, \mathrm{CV}$ : Coefficient of Variation

Effects of different nitrogen and zinc doses on the first cob height were found to be significant. In terms of nitrogen doses, the greatest first cob height $(53.67 \mathrm{~cm})$ was observed in $\mathrm{N}_{30}$ treatment, it was followed by $\mathrm{N}_{15}$ treatment $(53.67 \mathrm{~cm})$ and the lowest first cob height $(51.58 \mathrm{~cm})$ was observed in $\mathrm{N}_{0}$ treatment. The first cob heights increased with increasing nitrogen doses. Gözübenli (1997), Sezer and Yanbeyi (1997), Kara et al. (1999), Saruhan and Şireli (2005), Turgut (2000), Ülger et al. (1986), Uslu (1999) and Çokkızgın (2002) reported increasing cob heights with increasing nitrogen doses. In terms of zinc doses, the greatest first cob height $(55.60 \mathrm{~cm})$ was obtained from $\mathrm{Zn}_{0}$ 
treatment, it was followed by $\mathrm{Zn}_{5}$ treatment $(52.60 \mathrm{~cm})$ and the lowest value $(52.41 \mathrm{~cm})$ was obtained from $\mathrm{Zn}_{10}$ treatment. The first cob heights decreased with increasing zinc doses.

Effects of different nitrogen and zinc doses on cob thickness were found to be significant. In terms of nitrogen doses, the greatest cob thickness $(46.04 \mathrm{~mm})$ was observed in $\mathrm{N}_{15}$ treatment, it was followed by $\mathrm{N}_{30}$ treatment $(45.53 \mathrm{~mm})$ and the lowest cob thickness $(42.41 \mathrm{~mm})$ was observed in $\mathrm{N}_{0}$ treatment. Sezer and Yanbeyi (1997), Kara et al. (1999), Nimje and Seth (1988), Kaplan and Aktaş (1993), Çokkızgın (2002), Saruhan and Şireli (2005) and Turgut (2000) reported increasing cob thickness with increasing nitrogen doses. Ülger et al. (1996) reported that nitrogenous fertilizer treatments increased cob thickness as compared to the control treatment, but differences in cob thickness of 10, 20 and $30 \mathrm{~kg} / \mathrm{da}$ nitrogen treatments were not found to be significant. Aydın (1991) indicated that nitrogen doses of up to $20 \mathrm{~kg} / \mathrm{da}$ increased cob thickness and further increase in nitrogen doses did not have significant effects on cob thickness. In terms of zinc doses, the greatest cob thickness $\left(45.87 \mathrm{~mm}\right.$ ) was obtained from $\mathrm{Zn}_{0}$ treatment, it was followed by $\mathrm{Zn}_{5}$ treatment (44.78 $\mathrm{mm})$ and the lowest cob thickness $\left(43.58 \mathrm{~mm}\right.$ ) was obtained from $\mathrm{Zn}_{10}$ treatment. Cob thickness decreased with increasing zinc doses.

While nitrogen doses have significant effects on cob lengths, effects of zinc doses on cob lengths were not found to be significant. In terms of nitrogen doses, the greatest cob length $(17.84 \mathrm{~cm})$ was observed in $\mathrm{N}_{30}$ treatment, it was followed by $\mathrm{N}_{15}$ treatment $(17.30 \mathrm{~cm})$ and the lowest cob length $(14.91 \mathrm{~cm})$ was observed in $\mathrm{N}_{0}$ treatment. Gözübenli (1997), Sezer and Yanbeyi (1997), Kara et al. (1999), Nimje and Seth (1988), Kaplan and Aktaş (1993), Uslu (1999), Saruhan and Şireli (2005) and Turgut (2000) reported increasing cob lengths with increasing nitrogen doses. In terms of zinc doses, the greatest cob length $(16.84 \mathrm{~cm})$ was obtained from $\mathrm{Zn}_{10}$ treatment, it was followed by $\mathrm{Zn}_{5}$ treatment $(16.70 \mathrm{~cm})$ and the lowest cob length $(16.51 \mathrm{~cm})$ was obtained from $\mathrm{Zn}$ o treatment. Cob lengths increased with increasing zinc doses.

The greatest number of rows per cob (34.33 rows) was observed in $\mathrm{N}_{15}$ treatment, it was followed by $\mathrm{N}_{30}$ treatment (33.58 rows) and the lowest value (27.71 rows) was observed in $\mathrm{N}_{0}$ treatment. Köycü and Yanıkoğlu (1987), Ogunlela et al. (1988), Çokkızgın (2002), Sağlamtimur and Okant (1987) and Öktem (1996) indicated that cob lengths, a vegetative component of the plant, may vary based on nitrogenous fertilization. Uslu (1999) reported that nitrogen increased number of rows per cob, but differences in number of rows per cob of $\mathrm{N}_{25}$ and $\mathrm{N}_{35}$ treatments were not significant. In terms of zinc doses, the greatest number of rows per cob (32.26 rows) was obtained from $\mathrm{Zn}_{5}$ treatment, it was followed by $\mathrm{Zn}_{10}$ treatment (32.07 rows) and the lowest value (31.28 rows) was obtained from $\mathrm{Zn}_{0}$ treatment. Number of rows per cob increased up to $\mathrm{Zn}_{5}$ dose.

As can be inferred from Table 2, the greatest number of kernels per cob (583.5 kernels) was observed in $\mathrm{N}_{15}$ treatment, it was followed by $\mathrm{N}_{30}$ treatment (583.4 kernels) and the lowest number of kernels per cob (461.5 kernels) was observed in $\mathrm{N}_{0}$ treatment. With increasing nitrogen doses, plant growth and development were improved, thus cob length, diameter and yield components including number of kernels per cob were positively influenced (Kün, 1994; Turgut, 2000). Similar with the present findings, Weinhold et al. (1995), Gözübenli (1997), Suphot and Kitima (1977), Nimje and Seth (1988), Aydın (1991), Kaplan and Aktaş (1993), Ülger et al. (1997), Turgut (2000), Gökmen et al. (2001) and Presterl et al. (2003) reported increasing number of kernels per cob with increasing nitrogen doses. Uslu (1999) also reported increasing number of kernels per cob with increasing nitrogen treatments, but the differences between $\mathrm{N}_{25}$ and $\mathrm{N}_{35}$ treatments were not significant. In terms of zinc doses, the greatest number of kernels per cob (555.8 kernels) was obtained from $\mathrm{Zn}_{10}$ treatment, it was followed by $\mathrm{Zn}_{5}$ treatment (538.0 
kernels) and the lowest number of kernels per cob (534.6 kernels) was obtained from $\mathrm{Zn}_{0}$ treatment. Increasing zinc doses increased number of kernels per cob, but the differences in number of kernels per cob values of the zinc treatments were not found to be significant.

Table 2. Effects of nitrogen and zinc doses on number of rows per cob, number of kernels per cob, thou sand kernel weight and kernel yield

\begin{tabular}{lllll}
\hline Nitrogen Doses & $\begin{array}{l}\text { Number of } \\
\text { Rows per Cob }\end{array}$ & $\begin{array}{l}\text { Number of } \\
\text { Kernels per Cob }\end{array}$ & $\begin{array}{l}\text { Thousand } \\
\text { Kernel Weight } \\
(\mathrm{g})\end{array}$ & $\begin{array}{l}\text { Kernel Yield } \\
(\mathrm{kg} / \mathrm{da})\end{array}$ \\
\hline N0 & $27.71 \mathrm{~b}$ & $461.5 \mathrm{~b}$ & $302.2 \mathrm{~b}$ & $829.0 \mathrm{c}$ \\
N15 & $34.33 \mathrm{a}$ & $583.5 \mathrm{a}$ & $339.5 \mathrm{a}$ & $1000.9 \mathrm{a}$ \\
$\mathrm{N} 30$ & $33.58 \mathrm{a}$ & $583.4 \mathrm{a}$ & $311.8 \mathrm{~b}$ & $879.8 \mathrm{~b}$ \\
\hline LSD & 0.80 & 24.10 & 0.24 & 0.12 \\
\hline Zinc Doses & & & & \\
\hline Zn0 & $31.28 \mathrm{~b}$ & $534.6 \mathrm{a}$ & $331.1 \mathrm{a}$ & $944.9 \mathrm{a}$ \\
Zn5 & $32.26 \mathrm{a}$ & $538.0 \mathrm{a}$ & $306.8 \mathrm{~b}$ & $923.7 \mathrm{a}$ \\
Zn10 & $32.07 \mathrm{ab}$ & $555.8 \mathrm{a}$ & $315.5 \mathrm{ab}$ & $841.2 \mathrm{~b}$ \\
\hline LSD & 0.80 & 24.10 & 0.24 & 0.12 \\
CV $(\%)$ & 2.4 & 4.32 & 13.58 & 6.55 \\
\hline
\end{tabular}

** Significant at $\mathrm{P}<0.01, *$ Significant at $\mathrm{P}<0.05, \mathrm{CV}$ : Coefficient of Variation

The greatest thousand kernel weight (339.5 g) was observed in $\mathrm{N}_{15}$ treatment, it was followed by $\mathrm{N}_{30}$ treatment $(311.8 \mathrm{~g})$ and the lowest thousand kernel weight $(302.2 \mathrm{~g})$ was observed in $\mathrm{N}_{0}$ treatment. Nitrogenous fertilizers increase leaf area during the vegetative development, thus dry matter accumulation is greater during the grain fill period (Tolenaar et al., 1997). Such a case indicates that thousand kernel weight was positively influenced by increasing nitrogen doses. Present findings comply with the results of Ülger et al. (1986), Nimje and Seth (1988), Kaplan et al. (1993), Sade and Çalış (1993), Gözübenli (1997), Gökmen et al. (2001), Tüfekçi and Karaltın, (2001) and Amaral et al. (2005). Aydin (1991) also reported increasing thousand kernel weights with increasing nitrogen doses, but such an increase was quite low after $20 \mathrm{~kg} / \mathrm{da} \mathrm{N}$ dose. In terms of zinc doses, the greatest thousand kernel weight $\left(311.1 \mathrm{~g}\right.$ ) was obtained from $\mathrm{Zn}_{0}$ treatment, it was followed by $\mathrm{Zn}_{10}$ treatment $(315.5 \mathrm{~g})$ and the lowest thousand kernel weight (306.8 g) was obtained from $\mathrm{Zn}_{5}$ treatment. Increasing zinc doses did not have significant effects on thousand kernel weight.

In terms of nitrogen doses, the greatest kernel yield ( $1000.9 \mathrm{~kg} / \mathrm{da})$ was observed in $\mathrm{N}_{15}$ treatment, it was followed by $\mathrm{N}_{30}$ treatment $(879.8 \mathrm{~kg} / \mathrm{da})$ and the lowest kernel yield $(829.0 \mathrm{~kg} / \mathrm{da})$ was observed in $\mathrm{N}_{0}$ treatment. With increasing nitrogen doses, plant vegetative organs exhibit better development, thus greater photosynthesis, dry matter production and kernel nutrients and yields are achieved. (Schussler and Westgate, 1995, Tolenaar et al., 1997). Similarly, Podalak (1984), Ülger et al. (1996), Gözübenli (1997), Sezer and Yanbeyi (1997), William and Randall (1997), Schmidt et al. (1998), Ülger (1998), Allen et al. (2000), Öktem et al. (2001), Tüfekçi and Karaltın (2001), Blumenthal et al. (2003), Kamara et al. (2003), Presterl et al. (2003) and Saruhan and Şireli (2005) reported increasing kernel yields with increasing nitrogen doses. Uslu (1999) also reported increasing kernel yields with increasing nitrogen doses, but the differences between $\mathrm{N}_{25}$ and $\mathrm{N}_{35}$ treatments were not significant. Çokkızgin (2002) indicated that nitrogen doses of greater than 25 
$\mathrm{kg} / \mathrm{da} \mathrm{N}$ did not increase kernel yields. In terms of zinc doses, the greatest kernel yield $(944.9 \mathrm{~kg} / \mathrm{da})$ was obtained from $\mathrm{Zn}_{0}$ treatment, it was followed by $\mathrm{Zn}_{5}$ treatment $(923.7 \mathrm{~kg} / \mathrm{da})$ and the lowest kernel yield $(841.2 \mathrm{~kg} / \mathrm{da})$ was obtained from $\mathrm{Zn}_{10}$ treatment.

\section{CONCLUSIONS}

Present findings revealed that nitrogen and zinc treatments had significant effects on the first cob height, cob length, cob thickness, number of rows per cob, number of kernels per cob and kernel yield of maize plants. Effects of nitrogen and zinc treatments on plant height and thousand kernel weight were not found to be significant.

Increasing nitrogen doses had significant positive effects on yield and yield components. However, differences in investigated parameters of N15 and N30 treatments were not found to be significant. Since the primary target of the present study was to find out proper nitrogen dose for better yields in maize, it was concluded that N15 dose could be sufficient to get high yields from maize plants.

It was observed that increasing zinc doses did not have muck significant effects on yield and yield components. In terms of zinc doses, greatest values were generally obtained from $\mathrm{Zn} 0$ treatment.

\section{ACKNOWLEDGEMENTS}

This study was derived from a Graduate Thesis.

\section{REFERENCES}

Anonim, (2019a). [http://www.zmo.org.tr/genel/bizden_detay.php?kod=30187\&tipi=17\&sube=0), Erişim Tarihi: 18.09.2019.

Amaral, C.P.R., Filho, D.F., Farinelli, R., Barbosa, J.K. (2005). Row spacing, population density and nitrogen fertilization in maize. Rev. Bras. Cienc. Solo Vol. 29, No:3, Vicosa May/June 2005.

Aydın, H. (1991). Çukurova Koşullarında II. Ürün Mısır Bitkisinde (Zea mays L.) Değişik Azot Dozları ve Sıra Arası Mesafelerin Verim ve Verim Unsurlarına Etkisi [In Çukurova Conditions II. The Effect of Different Nitrogen Doses and Row Spacing on Yield and Yield Components in Crop Corn (Zea mays L.)]. Çukurova Üniversitesi Fen Bilimleri Enstitüsü, Tarla Bitkileri Anabilim Dalı, Yüksek Lisans Tezi. Adana.

Babaoğlu, M. (2005). Mısır ve Tarımı [Corn and its Agriculture]. Trakya Tarımsal Araştırma Enstitüsü, Edirne.

Bozcuk, S. (1986). Bitki Fizyolojisi. [Plant Physiology.] Hatipoğlu Yayınevi.

Brohi, A.R., Karaata, H., Özcan, S., Demir, M. (2000). Topraktan ve Yapraktan Çinko Uygulamasının Ekmeklik Buğday Bitkisinin Verimine ve Bazı Besin Maddesi Alımına Etkisi [The Effect of Soil and Foliar Zinc Application on the Yield and Some Nutrient Uptake of Bread Wheat Plant]. GOP Üniversitesi, Ziraat Fakültesi Dergisi, Cilt:17, 123-128.

Cihangir, H. (2013). Organik Yetiştirilen Cin Mısırı (Zea mays L. everta) ve Tatlı Mısırda (Zea mays L. saccharata) Farklı Besin Kaynaklarının Verim ve Kalite Üzerine Etkisi [The Effect of Different Nutrient Sources on Yield and Quality in Organically Grown Gin Corn (Zea mays L. everta) and Sweet Corn (Zea mays L. saccharata)]. Harran Üniversitesi Fen Bilimleri Enstitüsü, Doktora Tezi, Şanlıurfa. Sayfa 162.

Çokkızgın, A. (2002). Kahramanmaraş Koşullarında Farklı Azot Dozları İle Sıra Üzeri Ekim Mesafelerinin 2. Ürün Misır (Zea mays L.) Bitkisinde Verim, Verim Unsurları ve Fizyolojik Özelliklere Etkisi [The Effect of Different Nitrogen Doses and In-Row Sowing Distances on Yield, Yield Components and Physiological Properties in 2nd Crop Corn (Zea mays L.) Plant in Kahramanmaraş Conditions]. Kahramanmaraş Sütçü İmam Üniversitesi Fen Bilimleri Enstitüsü, Yüksek Lisans Tezi, Kahramanmaraş.

Çolakoğlu, H. (2010). Misır Bitkisinde Gübreleme [Fertilization in Corn Plant] [http://www.toros.com.tr/CiftciDostu/GubrelemeOnerileri/ MisirBitkisindeGubreleme], Erişim Tarihi:20.09.2019.

Demari, G.H., Carvolho, I.R., Nardino, M., Szaresk1, V.J., Dellagostın, S.M., Rosa, T.C., Follman, D.N., Monteiro, M.A., Basso, C.J., Pedo, T., Aumonde, T.Z., Zimmer, P.D. (2016) Importance of Nitrogen in Maize Production. Journal Of Current Research. 
Dumral, Ç.H.N. 2015. Farklı Çinko Dozlarının Mısır (Zea Mays L.) Çeşitlerinde Verim ve Tane Kalitesi Üzerine Etkisi [The Effect of Different Zinc Doses on Yield and Grain Quality of Maize (Zea Mays L.) Varieties]. Adnan Menderes Üniversitesi Fen Bilimleri Enstitüsü Tarla Bitkileri Anabilim Dal, Yüksek Lisans Tezi. Aydın

El-Hattab, H.S., Hussein, M.A., El-Hattab, A.H., Abdel Raouf, M. S., El-Nomany, A.A. 1980. Growth Analysis of Maize Plant In Relation to Grain Yield As Affected By Nitrogen Levels. Z. Acker-Und Pflanzenbau ( $J$. Agronomy \& Crop Science), 149: 46-57.

Engin, İ., Tosun, M., Soya, H. 1989. Üç Mısır Çeşidinde Farklı Ekim Zamanının Tane Verimi ve Bazı Verim Karakterleri Üzerine Etkisi [The Effect of Different Sowing Times on Grain Yield and Some Yield Characteristics in Three Corn Varieties]. Ege Üniversitesi Ziraat Fakültesi Dergisi. Cilt:26, Say1 1-3.

Evans, C. L. 1972. The Qualitative Analysis of Plant Growth. Blackwell Scientific Publication, London.

Flesh, R.D., Veira, L.C. 2000. Spacing and Plant Density in Maize Cultivation. Field Crop Abstracts, Vol:53 No: 1

Gençkan, M. S. 1976. Tohumluk [Seeds]. Ege Üniversitesi, Ziraat Fakültesi Yayınları, No:253.

Gökmen, S., Sencar, Ö., Sakin, M.A. 2001. Response of Popcorn (Zea mays verta) to Nitrogen Rates and Plant Densities. Turk. J. Agric. For., 25 (2001), 15-23.

Gözübenli, H. 1997. Değişik Azot Uygulamalarında 2. Ürün Olarak Yetiştirilen Bazı Misır Genotiplerinin Azot Kullanım Etkinliğinin Saptanması [Determination of Nitrogen Utilization Efficiency of Some Corn Genotypes Grown as Second Crop in Different Nitrogen Applications]. Çukurova Üniversitesi, Fen Bilimleri Enstitüsü, Doktora Tezi. Kod No:380 Adana.

Kara, Ş.M., Deveci, M., Dede, Ö., Şekeroğlu, N. 1999. Farklı Bitki Sıklığı ve Azot Dozlarının Silaj Mısırda Yeşil Ot Verimi ve Bazı Özellikler Üzerine Etkileri [The Effects of Different Plant Density and Nitrogen Doses on Green Grass Yield and Some Properties in Silage Corn]. Türkiye III. Tarla Bitkileri Kongresi, 15-18 Kasım 1999, (Sunulu Bildiri) Cilt. III, Çayır-Mera Yem Bitkileri ve Yemeklik Tane Baklagiller, Adana, 172-178.

Kaplan, M., Aktaş, M. 1993. Amonyum Nitrat ve Üre Gübrelerinin Hibrit Mısırda Etkinliklerinin Karşılaştırılması ve Bu Bitkinin Azotlu Gübre İsteğinin Belirlenmesi [Comparison of the Efficiency of Ammonium Nitrate and Urea Fertilizers in Hybrid Corn and Determination of Nitrogen Fertilizer Demand of This Plant]. Doğa-TR. J. Of Agricultural and Forestry. 17:649-657.

Köycü, C., Yanıkoglu, S. 1987. Samsun Ekolojik Şartlarında Mısır (Zea mays 1.) Çeşit ve Ekim Zamanı Üzerinde Bir Araştırma [A Research on Maize (Zea mays 1.) Variety and Sowing Time in Samsun Ecological Conditions]. Türkiye Mısır Üretiminin Geliştirilmesi, Problemler ve Çözüm Yolları Sempozyumu, 23-26 Mart, 287-302s. Ankara

Kün, E. 1994. Tahıllar II. (Sicak İklim Tahıllar) [Cereals II. (Warm Climate Cereals)]. Ankara Üniversitesi Ziraat Fakültesi Yayınları: 1452, 1465. Ankara

Maiti, R., Wersche- Ebeling, P. 1998. Maize Science. Science Publichers, Inc. USA, ISBN 1-57808-019-3, s.519.

Nimje, P.M., Seth, J. 1988. Effect of Nitrogen on Growth, Yield and Quality of Winter Mazie. Indian J. Of Argon., 33(2):209-211.

Ogunlela, V.B., Amoruwa, G.M., Ologundei, O.O. 1998. Growth, Yield Components and Micronutrient Nutrion of Field-Grown (Zea mays L.) as Affected by Nitrojen Fertilization and Plant Density. Fertilizer Research, 17.

Öktem, A. 1996. Harran Ovası Koşullarında 2. Ürün Olarak Yetiştirilebilecek 10 Misır Genotipinde (Zea mays L.) Farklı Dozlarda Uygulanan Fosforun Verim ve Verim Unsurlarına Etkisi [The Effect of Phosphorus Applied in Different Doses on Yield and Yield Components in 10 Corn Genotypes (Zea mays L.) That Can Be Grown as a Second Crop in Harran Plain Conditions]. Ç.Ü. Fen Bilimleri Enstitüsü, Tarla Bitkileri Anabilimdall, Doktora Tezi. Adana.

Presterl, T., G, Seitz., M., Landbeck, E.M., Thiemt, W., Geiger, H.H. 2003. Improving Nitrogen-Use Efficiency in European Maize. Crop Science 43:1259-1265 (2003).

Sade B., Çalış, M. 1993. Erdemli Ekolojik Şartlarında İkinci Ürün Olarak Yetiştirilen Cin Mısır Populasyonlarının (Zea mays everta) Verim ve Verim Unsurları Üzerine Farklı Bitki Sıklıklarının Etkisi [The Effect of Different Plant Densities on Yield and Yield Components of Gin Corn Populations (Zea mays everta) Cultivated as Second Crop in Virtuous Ecological Conditions]. S.Ü. Ziraat Fakültesi Dergisi, 3(5):32-45.

Sağlamtimur, T., Okant, M. 1987. Güneydoğu Anadolu Bölgesi Sulanabilir Koşullarında 2. Ürün Misırda Çeşit ve Bitki Sıklığının Verim ve Bazı Tarımsal Karakterlere Etkisi Üzerine Bir Araştırma [Study on the Effect of Variety and Plant Density on Yield and Some Agricultural Characteristics in 2nd Crop Corn in Irrigated Conditions of the Southeastern Anatolia Region]. Türkiye'de Mısır Üretiminin Geliştirilmesi, Problemler ve Çözüm Yolları Sетровуити, 23-26 Mart, Ankara, 317-329. 
Saruhan, V., Şireli, H.D. 2005. Mısır Bitkisinde (Zea mays L.) Farklı Azot Dozları ve Bitki Sıklığının Koçan, Sap ve Yaprak Verimlerine Etkisi Üzerine Bir Araştırma [A Study on the Effect of Different Nitrogen Doses and Plant Density on Ear, Stalk and Leaf Yields in Corn Plant (Zea mays L.)]. Harran Üniversitesi Ziraat Fakültesi Dergisi, 2005, 9 (2):45-53.

SAS, Inst. 1999. SAS Institute Inc., Cary, NC, USA.

Shaw, R.H. 1988. Climate Requirement Corn and Corn Improvement. ASA, CSSA, SSSA, 609638, Wisconsin, USA.

Sencar, Ö. 1988. Mısır Yetiştiriciliğinde Sıklık ve Azotun Etkileri [Frequency and Effects of Nitrogen in Corn Cultivation]. Cumhuriyet Üniversitesi, Tokat Ziraat Fakültesi Yayınları:6, Araştırma ve İncelemeler 3, Tokat.

Suphot, P., Kitıma, M. 1997. Effect Of Nitrogen Fertilizer on Nitrate Reductase, Grain Yield and Some Agronomik Characteristics İn Corn (Zea mays L.). (Agris 1981-1985) Kassetsart Journal, 11(1-2);33-49.

Sezer, İ., Yanbeyi, S. 1997. Çarşamba Ovasında Yetiştirilen Cin Mısırda (Zea mays L.) Bitki Sıklı̆̆1 ve Azotlu Gübrenin Tane Verimi, Verim Komponentleri ve Bazı Bitkisel Karakterler Üzerine Etkisi [The Effect of Plant Density and Nitrogen Fertilizer on Grain Yield, Yield Components and Some Plant Characteristics in Gin Corn (Zea mays L.) Cultivated in Çarşamba Plain]. Türkiye II. Tarla Bitkileri Kongresi, 22-25 Eylül, Samsun, (128133s).

Şehirali, S., Gençtan, T., Birsin, M.A., Zencirci, N., Uçkesen, B. 2000. Türkiye Tahıl ve Yemeklik Tane Baklagil Üretiminin Bugünkü ve Gelecekteki Boyutları [Current and Future Dimensions of Cereal and Edible Grain Legumes Production in Turkey]. T.Ü. Ziraat Fakültesi, Tarla Bitkileri Bölümü, Tekirdağ., A.Ü. Ziraat Fakültesi, Tarla Bitkileri Bölümü, Ankara., Tarla Bitkileri Merkez Araştırma Enstitüsü, Ankara.

Tolenaar, M., Aguilera, A., Nisanka, S.P. 1997. Grain Yield in Reducedmore by Weed Interfrence in an Old Than in a New Maize Hybrid. Argon. J., 89:239-246.

Turgut, İ. 2000. Bursa Koşullarında Yetiştirilen Şeker Mısırında (Zea mays Sacchara Sturt.) Bitki Sıklığının ve Azot Dozlarının Taze Koçan Verimi İle Verim Öğeleri Üzerine Etkisi [The Effect of Plant Density and Nitrogen Doses on Fresh Cob Yield and Yield Components in Sugar Corn (Zea mays Sacchara Sturt.) Grown in Bursa Conditions]. Turkish Journal of Agriculture and Forestry, 2000, 24(3):341-347.

Tüfekçi, A., Karaltın, S. 2001. Kahramanmaraş Koşullarında 1. Ürün Olarak Yetiştirilen Mısır (Zea mays L.) Bitkisinde Farklı Azot Dozlarının Verim ve Verim Unsurlarına Etkisi [The Effect of Different Nitrogen Doses on Yield and Yield Components of Corn (Zea mays L.) Grown as the 1st Crop in Kahramanmaraş Conditions]. Türkiye IV. Tarla Bitkileri Kongresi, 17-21 Eylül 2001, Tekirdağ, 291-295.

Uslu, Ö.S. 1999. Kahramanmaraş Koşullarında 2. Ürün Olarak Yetiştirilen Mısır (Zea mays L.) Bitkisinde Farklı Azot Dozlarının Büyüme ve Fizyolojik Özelliklere Etkisi [The Effect of Different Nitrogen Doses on Growth and Physiological Characteristics of Corn (Zea mays L.) Grown as a Second Crop in Kahramanmaraş Conditions]. K.S.Ü., Fen Bilimleri Enstitüsü, Yüksek Lisans Tezi (Basılmamış), Kahramanmaraş.

Ülger, A.C. 1986. Reaksion Verschiederner Mais-Inzuhtlinen und Hybriden auf Steigendes Stichstoffangebat Dissertation, University Hohenhaim, Stuttgart, Germany, 22, No:2.

Ülger, A.C., Tansı, V., Sağlamtimur, T., Kızılşimşek, M., Çakır, B., Yücel, C., Baytekin, H., Öktem, A. 1996. Güneydoğu Anadolu Bölgesinde İkinci Ürün Mısırda, Bitki Sıklığı ve Azotlu Gübrelemenin Tane ve Hasıl Verimi ve Bazı Tarımsal Karakterlerine Etkisi Üzerine Araştırmalar [Studies on the Effect of Plant Density and Nitrogen Fertilization on Grain and Yield Yield and Some Agricultural Characteristics in Second Crop Corn in the Southeastern Anatolia Region]. Ç.Ü.Z.F. GAP Tarımsal Araştırma Inceleme ve Geliştirme Proje Paketi Kesin Sonuç Raporu, Proje No:12\1. Ç.Ü.Z.F. Genel Yayın No: 153 GAP Yayınları No 94(45s.).

Welnhold, B.J., Trooien, T.P., Reichman, G.A. 1995. Yield and nitrogen use efficiency of irrigated corn in the northern dreat plains. Agronomy Journal, 87; 842-84.

West, C., Buriggs, G.E., Kidd, F. 1920. Methods and Significant Relations in The Quantitative Analysis of Plant Growth. New Phytol., 19:200-207.

Yürürdurmaz, C. 2007. Kahramanmaraş Koşullarında Farklı Gübre Dozlarının Değişik Mısır Çeşitlerine Etkisinin Saptanması ve Ceres-Maize Bitki Büyüme Modelinin Değerlendirilmesi [Determination of the Effect of Different Fertilizer Doses on Different Corn Varieties in Kahramanmaraş Conditions and Evaluation of CeresMaize Plant Growth Model], Çukurova Üniversitesi Fen Bilimleri Enstitüsü Tarla Bitkileri Anabilim Dalı Doktora Tezi, Adana. 